\title{
Erectile dysfunction: management update
}

\section{Luke Fazio, Gerald Brock}

\section{Abstract}

DRAMATIC ADVANCES IN THE MANAGEMENT of erectile dysfunction have occurred over the past decade. Oral therapy with vasoactive agents has emerged as first-line treatment and has transformed both the manner in which the public views erectile dysfunction and the way health care providers deliver care. Whereas an extensive investigation was previously common in the management of erectile dysfunction, recent treatment guidelines promote a more minimalist, goal-oriented approach. In this article, we review the physiology of erection, and the pathophysiology, diagnosis and clinical management of erectile dysfunction. We also present the existing evidence for the efficacy of 3 phosphodiesterase inhibitors, the most widely used class of agents for erectile dysfunction.

CMAJ 2004;170(9):1429-37

$\mathrm{E}$ rectile dysfunction can be defined as the inability to achieve or maintain a penile erection sufficient for satisfactory sexual performance. ${ }^{1}$ In the face of an aging population, decreasing social stigma associated with erectile dysfunction and an increasing availability of effective oral therapy for its treatment, the number of patients presenting with this complaint has increased dramatically. Current estimates describe 2-3 million Canadian men as having significant recurring erectile difficulties. Recent reports identifying a dramatic increase in rates of diabetes, increased longevity and higher quality-of-life expectations by "baby boomers" are all believed to be factors in a projected continued expansion of the patient population requesting medical help with sexual issues in the near future. ${ }^{2,3} \mathrm{Al}$ though historically erectile dysfunction was a problem identified and treated by urologists, today primary care physicians and other specialists write $80 \%$ of the prescriptions for sildenafil, the most popular drug used to treat the condition. ${ }^{4}$

In this article, we review the epidemiology of erectile dysfunction, the current understanding of its pathophysiology and the evidence for the efficacy of oral therapy with a phosphodiesterase type- 5 inhibitors, which has become the first-line treatment of erectile dysfunction.

\section{Epidemiology of erectile dysfunction}

The Massachusetts Male Aging Study surveyed 1709 men aged 40-70 years in the greater Boston area between 1987 and 1989 and reported a prevalence of erectile dys- function of $52 \%$, with $9.6 \%$ of respondents reporting complete erectile dysfunction. ${ }^{5}$ In 2000 the overall prevalence of erectile dysfunction in this study population was reestimated to be $44 \%{ }^{6}$ The Massachusetts study is important because it is the first cross-sectional, communitybased, random-sample multidisciplinary survey on the topic and involved a significant cohort followed up for nearly a decade beyond the initial assessment. A survey of 3009 men aged 18-70 years from all regions of Canada revealed a similar prevalence of erectile dysfunction.?

\section{Physiology of an erection}

Erection involves the integration of neural and vascular functions. In essence, an erection occurs when blood flow to the penis exceeds flow out of the penis. The cavernosal arteries supply blood to the corpora cavernosa of the penis (through the pudendal artery); the emissary veins running through the tunica albuginea allow drainage. During erection, relaxation of trabecular smooth muscle results in increased blood flow to the corpora cavernosa and expansion of the sinusoids therein. This distension causes mechanical compression of the emissary veins, which impedes their ability to drain blood and thereby results in penile rigidity (Fig. 1).

Penile blood flow is controlled by the autonomic erection centre, which provides parasympathetic $\left(\mathrm{S}_{2}-\mathrm{S}_{4}\right)$ and sympathetic $\left(\mathrm{T}_{12}-\mathrm{L}_{2}\right)$ input to the pelvic plexus, ${ }^{8}$ including the cavernous nerves that innervate the cavernosal arteries and trabecular smooth muscle. These nerves are responsible for the delivery of high local concentrations of nitric oxide to the trabecular smooth muscle, which results in relaxation (Fig. 2). ${ }^{9,10}$ Nitric oxide diffuses across the smooth-muscle membrane and activates guanylate cyclase to produce cyclic guanosine monophosphate (cGMP); the biochemical cascade that ensues results in altered potassium and calcium ion channel permeability; ultimately, the decrease in cytosolic calcium concentration causes smoothmuscle relaxation and increased regional blood flow. ${ }^{11,12}$ Phosphodiesterase enzymes (PDEs) regulate this pathway by inactivating cGMP, which results in elevated cytosolic calcium concentrations and smooth-muscle contraction. PDE type 5 is the most important isoenzyme in the corpora cavernosa. ${ }^{13-15}$

The somatic motor nerve supply arises from the sacral spinal cord, whose fibers join the pudendal nerve innervating the bulbocavernosus and ischiocavernosus muscles, ac- 


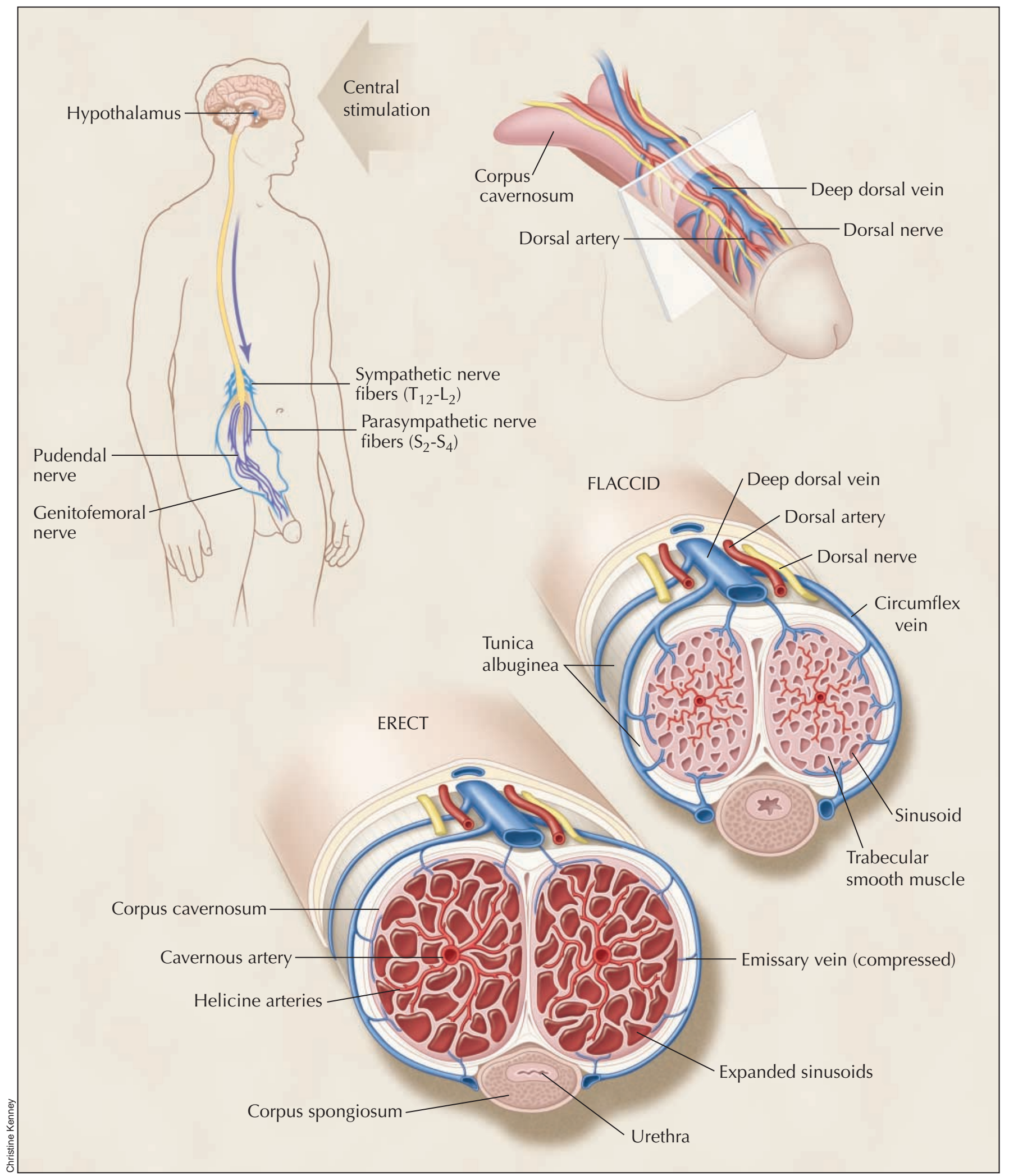

Fig. 1: Anatomy and mechanism of penile erection. The erection pathway can be triggered by direct genital stimulation and by auditory and visual stimulation, which act in concert to increase penile blood flow. The penis has a highly specialized anatomical structure that allows a massive increase in blood flow to be trapped within the inelastic layers surrounding the penis (the tunica albuginea), which causes rigidity and expansion of the cavernosal smooth muscle. 
tive during ejaculation and climax. Adrenergic stimulation is responsible for cavernous smooth-muscle contraction and detumescence. Cholinergic nerves may contribute to the erectile process through adrenergic inhibition as well as by causing release of nitric oxide from the endothelium. ${ }^{16}$

Three mechanisms trigger these vascular changes: psychogenic, reflexogenic and centrally originated (nocturnal erections). Psychogenic erections occur through stimulatory pathways (e.g., sound, smell, sight and touch) that travel from the spinal erection centres $\left(\mathrm{T}_{11}-\mathrm{L}_{2}\right.$ and $\left.\mathrm{S}_{2}-\mathrm{S}_{4}\right)$ and induce a dopaminergic initiation of erection from the medial pre-optic area. ${ }^{17}$ Reflexogenic erections, induced by direct genital stimulation, send ascending messages to the central erection centres and direct messages to the autonomic nuclei, which explains residual erectile activity in patients with upper spinal cord injuries. Nocturnal erections, initiated in the pontine reticular formation and amygdalae, are seen during REM sleep and are believed to be caused by a relative decrease in sympathetic inhibition with augmentation of the pro-erectile centres.

Despite considerable recent experimentation in animal models and human volunteers, information on the central pathways of erection remains cursory at best. ${ }^{18}$ It is known that androgens play a predominantly modulating role by their effect on libido and sexual behaviour. Testosterone enhances sexual interest and the frequency of sexual acts; it increases the frequency of nocturnal erections but does not effect reflexogenic or psychogenic erections. ${ }^{19}$

\section{Pathophysiology of erectile dysfunction}

Numerous factors can disrupt the normal physiologic mechanisms involved in erection (Table 1). Most cases of erectile dysfunction were thought to be psychologically based, but it is now understood that most have an organic cause, especially in older patients. In about $40 \%$ of men over 50 years old, the primary cause of erectile dysfunction is related to atherosclerotic disease. ${ }^{20}$ In this respect, risk factors are similar to those of cardiovascular disease. However, erectile dysfunction may also be related to psychological, neurological, hormonal, pharmacological and endorgan (penile) factors.

With respect to neurological causes, involvement of any nerve group, either central or peripheral, may lead to erectile dysfunction. Cerebral diseases lead to decreased sexual interest, possibly through over-inhibition of spinal centres. Among patients with spinal cord injury, 95\% of those who have upper motor neuron lesions are capable of reflexo-

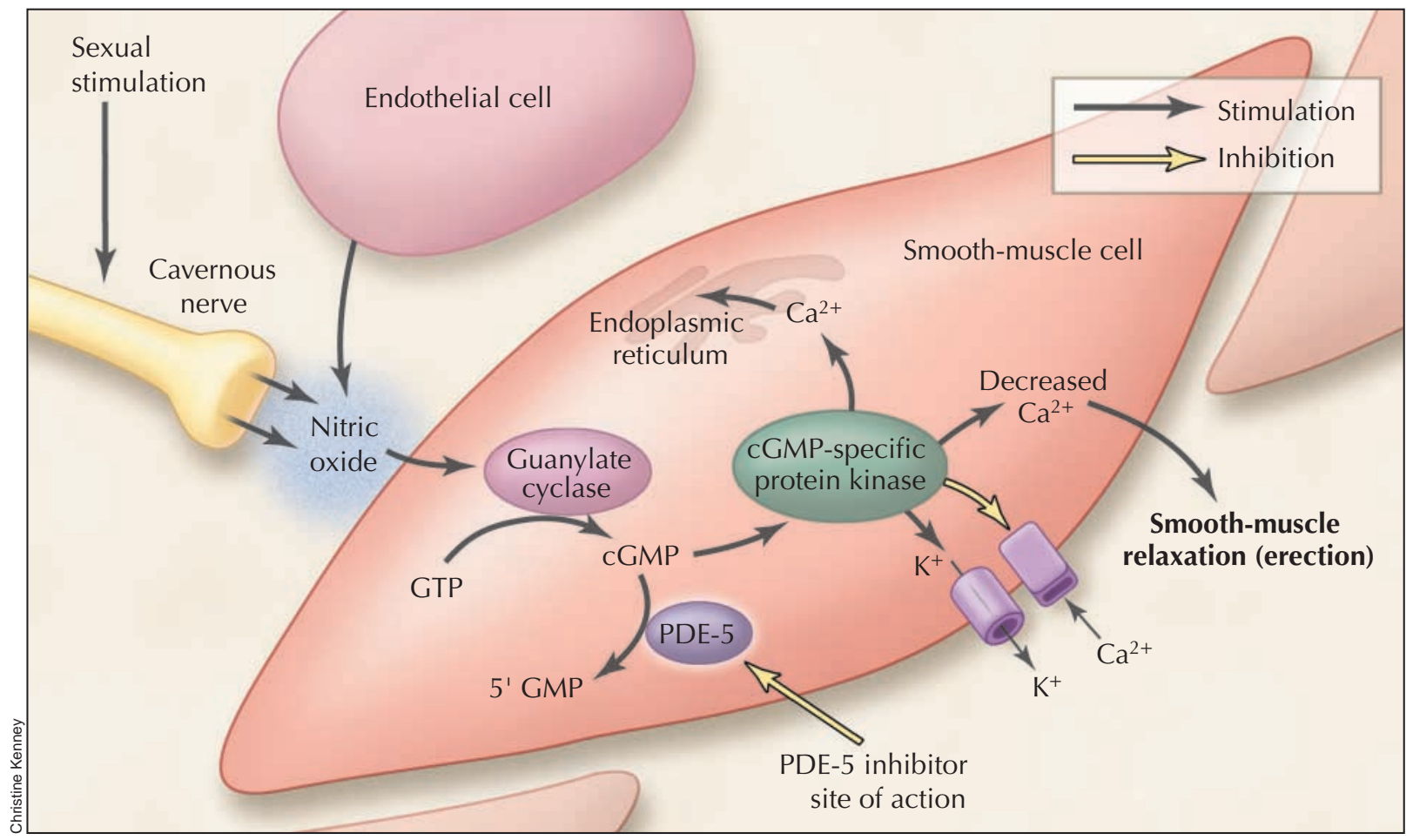

Fig. 2: Cellular perspective of the erection pathway. The signal (nitric oxide) is released from nerve endings or from endothelial cells and activates a cascade reaction, which ultimately leads to an increased cellular concentration of cGMP (cyclic guanosine monophosphate). This second messenger molecule induces a series of events that lead to smooth-muscle relaxation through a reduction in the intracellular calcium ion concentration. The enzyme PDE-5 (phosphodiesterase type 5) reverses this effect by metabolizing the cGMP to GMP rapidly. The clinically important inhibitors of this enzyme (sildenafil, vardenafil and tadalafil) all act to promote smooth-muscle relaxation by their ability to allow cGMP to accumulate when nitric oxide is released, as is the case when sexual stimulation is present. 
genic erections, $25 \%$ of patients who have lower motor neuron lesions are capable of psychogenic erections, and more than $90 \%$ of patients who have incomplete lesions of either kind retain their erectile function. ${ }^{21}$ Direct injury to the cavernosal nerve and blood supply commonly occurs during therapy for prostate cancer; erectile dysfunction is present to some extent in $80 \%$ of patients so treated, whether by surgery or external beam radiation therapy. ${ }^{22}$

Almost all antihypertensive medications have been implicated in erectile dysfunction. ${ }^{23}$ The mechanisms vary from central-acting sympatholytics, depression of libido as well as higher blood pressure requirement to achieve erection in atherosclerotic patients taking diuretics and vasodilators. The role of smoking in causing erectile dysfunction remains a source of controversy. A recent consensus group analysis failed to document a direct link to erectile dysfunction. However, smoking seems to amplify other risk factors, such as hypertension and coronary artery disease. ${ }^{24}$ Martin-Morales and colleagues ${ }^{25}$ have shown an increased risk of erectile dysfunction among smokers (odds ratio [OR] 2.5). Systemic diseases are also associated with erectile dysfunction. This is often multifactorial, as in diabetes and renal failure. ${ }^{26}$ Given the role of androgens in the physiology of erections, it is not surprising that many hypogonadal men do not experience erectile dysfunction per se. Low serum testosterone levels may be primary or secondary to another condition, such as hyperprolactinemia or hypothyroidism. Regardless of the mechanism, the result is primarily a loss of libido, although many hypogonadal men retain their ability to obtain erections. ${ }^{27}$

The rich database of the Massachusetts Male Aging Study has allowed important insights to be gained into a variety of risk factors for erectile dysfunction, both psychosocial and physical. A submissive personality was associ-

\section{Table 1: Causes of erectile dysfunction}

\begin{tabular}{ll}
\hline Causes & \multicolumn{1}{c}{ Examples } \\
\hline $\begin{array}{l}\text { Aging } \\
\text { Psychological disorders } \\
\text { Neurological disorders }\end{array}$ & $\begin{array}{l}\text { Depression, anxiety } \\
\text { Cerebral diseases, spinal cord injury, spinal } \\
\text { disease, peripheral neuropathy, pudendal }\end{array}$ \\
& nerve injury \\
Hormonal disorders & hypogonadism, hyperprolactinemia, \\
(depresses libido) & $\begin{array}{l}\text { hyper- or hypothyroidism, Cushing's } \\
\text { syndrome, Addison's disease }\end{array}$ \\
Vascular disorders & $\begin{array}{l}\text { Atherosclerosis, ischemic heart disease, } \\
\text { peripheral vascular disease, venous } \\
\text { incompetence, cavernosal disorders }\end{array}$ \\
Antihypertensives, antidepressants \\
(depresses libido), estrogens and anti- \\
androgens (depresses libido), digoxin \\
Marijuana use, alcohol abuse, narcotics \\
use, cigarette smoking \\
Diabetes mellitus, renal failure, \\
hyperlipidemia, hypertension, chronic \\
obstructive pulmonary disease
\end{tabular}

ated with a higher risk of erectile dysfunction. Obesity status was also associated with the condition $(p=0.006)$, with baseline obesity predicting a higher risk regardless of follow-up weight loss. Smoking and alcohol consumption were not found to be causally associated with the incidence of erectile dysfunction. The risk of the condition was higher among men with lower education levels, diabetes, heart disease and hypertension.

\section{Diagnosis}

Just a decade or 2 ago, the routine evaluation of erectile dysfunction consisted of an exhaustive biochemical screening panel, psychological assessments and occasional vascular testing. This approach was justified as reasonable at the time, because the treatment options available were invasive. In contrast, current recommendations for management rely on history-taking and basic screening tests. The Canadian Urological Association has recently developed an algorithm for the management of erectile dysfunction that supports this approach. ${ }^{28}$

The most important component of diagnosing erectile dysfunction is obtaining a complete medical and sexual history. It is important to distinguish the condition from other sexual dysfunctions, such as premature ejaculation and loss of libido. Several formalized sexual questionnaires, such as the IIEF (Internation Index of Erectile Function) and EDITS (Erectile Dysfunction Inventory of Treatment Satisfaction), allow one to detect the presence and grade the severity of erectile dysfunction. The complete IIEF is composed of 15 questions; an abridged 5 -item version, called the sexual health inventory for men (SHIM), has been developed and validated. ${ }^{29}$ Allowing a patient to complete such a questionnaire before his first clinical encounter may produce a more comfortable clinical environment. ${ }^{30}$ The duration of the problem, time of onset and degree of patient and partner concern should also be elucidated. The circumstances surrounding erectile dysfunction may be helpful in determining whether a situational or nonorganic factor is involved. Sudden onset, maintenance of nocturnal erections, presence of psychological problems and concurrent major life events or relationship issues may be associated with nonorganic erectile dysfunction. ${ }^{31}$ Concurrent medical illnesses and any medications the patient may be taking should be reviewed. Erectile dysfunction is often a component of generalized medical illness and may represent the initial presentation of cardiovascular disease or diabetes. The history may also reveal certain reversible or modifiable risk factors, such as tobacco use or inadequate diabetes control.

The physical examination should focus on the vascular, neurological and endocrine systems. ${ }^{28,31}$ Testes size should be noted and the penis shaft examined to rule out a penile deformity (Peyronie's disease). With respect to laboratory investigations, recommendations vary, ${ }^{30,31}$ and investigations should follow clinical suspicion of specific disorders. He- 
moglobin $\mathrm{A}_{1 \mathrm{c}}$ and serum glucose may be measured to detect occult diabetes, and a lipid screen performed to assess the presence of dyslipidemia. Hormonal screening is controversial; however, it is reasonable to measure testosterone levels in the face of erectile dysfunction combined with loss of libido ${ }^{28}$ Patients in whom hyper- or hypothyroidism is suspected should have their thyroid-stimulating hormone level checked. ${ }^{30}$

A number of specialized investigations exist for the evaluation of erectile dysfunction but need not be part of the routine evaluation. The penile brachial index involves measuring penile pressure and comparing it with arm pressure. It has limited clinical utility because the data are based on superficial and deep penile arterial pressure, whereas erectile function depends on the deep arteries exclusively. Duplex ultrasonography allows for refined assessment of the penile circulation. The information it provides, however, is operator dependent and rarely alters patient management. Selective pudendal arteriography combined with intracavernous injection of a vasoactive drug should be limited to the small group of patients who are candidates for penile revascularization surgery. These patients include nonsmoking men less than 40 years old with a history of pelvic trauma who have sustained a penile arterial disruption. ${ }^{30}$

\section{Treatment}

\section{Oral therapy}

The use of oral therapy has long been preferred over invasive procedures such as injection therapy for erectile dysfunction. We review the pharmacology, efficacy and side effects of the newest agents available for oral therapy: the PDE-5 inhibitors sildenafil, vardenafil and tadalafil.
PDE-5 is an enzyme found in trabecular smooth muscle. It catalyzes the degradation of cGMP, which results in an elevated cytosolic calcium concentration and smoothmuscle contraction (Fig. 2). PDE-5 inhibitors, therefore, block this biochemical pathway to promote erection. Eleven subtypes of PDEs have been described, with 30 isoenzymes mediating a variety of physiologic actions throughout the body. ${ }^{32}$ PDEs exhibit enormous functional diversity; at present, our understanding of PDE types 1 to 6 are considerably better than our understanding of PDE types 7 to 11 .

All 3 of the PDE-5 inhibitors are metabolized by the cytochrome P-450 3A4 enzyme. Sildenafil and vardenafil share similar pharmacokinetic properties (Table 2). Both have been shown in clinical trials to improve the ability to attain and maintain erections when taken 1 hour before sexual activity (Table 3). Since sildenafil was introduced, extensive clinical experience has been gained with prescriptions of it to more than 20 million patients. Vardenafil has distinguished itself by demonstrating efficacy in patients who have previously undergone radical prostatectomy for localized prostate cancer (a group that had been difficult to treat because of nerve and vascular injury secondary to surgery) and in patients with diabetes. ${ }^{34,35}$

Tadalafil differs from sildenafil and vardenafil in its chemical structure and its lack of inhibition of PDE type 6. Tadalafil exhibits a prolonged half-life of 17.5 hours, and the time to peak concentration is about 2.0 (range 0.5-12.0) hours in healthy volunteers. ${ }^{37}$ Among men with erectile dysfunction, a significantly higher percentage of attempts at sexual intercourse were successful up to 24-36 hours after use of tadalafil compared with placebo..$^{37,40,41}$ The pharmacokinetics of tadalafil is not clinically influenced by food or alcohol intake, or by intrinsic factors such as diabetes, or renal or hepatic impairment. ${ }^{41}$

\begin{tabular}{|c|c|c|c|}
\hline Parameter & Sildenafil & Vardenafil & Tadalafil \\
\hline Oral dose, mg & 100 & 20 & 20 \\
\hline $\begin{array}{l}\text { Median time to peak concentration, } \\
\text { min }\end{array}$ & 60 & $40-60$ & 120 \\
\hline Half-life, h & $3-4$ & $4-5$ & 17.5 \\
\hline Maximum concentration, $\mu \mathrm{g} / \mathrm{L}$ & 411 & 17 & 378 \\
\hline Area under the erectile curve, $\mu \mathrm{g} \cdot \mathrm{h} / \mathrm{L}$ & 1691 & 67 & 8066 \\
\hline Volume of distribution, $\mathrm{L}$ & 105 & 208 & 63 \\
\hline Food interaction & $\begin{array}{l}\text { Yes with high-fat } \\
\text { foods; possible with } \\
\text { low-fat foods }\end{array}$ & $\begin{array}{l}\text { Minimal with low-fat } \\
\text { foods; delay in time to } \\
\text { peak concentration } \\
\text { with high-fat foods }\end{array}$ & None \\
\hline Alcohol interaction & None & None & None \\
\hline Age $>65 \mathrm{yr}$ & $\begin{array}{c}\text { Half-life } \uparrow \\
\text { Dose adjustment } \\
\text { may be needed }\end{array}$ & $\begin{array}{c}\text { Half-life } \uparrow \\
\text { Dose adjustment } \\
\text { may not be needed }\end{array}$ & $\begin{array}{c}\text { Half-life } \uparrow \\
\text { Dose adjustment } \\
\text { may not be needed }\end{array}$ \\
\hline
\end{tabular}

Note: PDE-5 = phosphodiesterase type 5 . 


\section{Adverse events}

The primary concern with oral therapy for erectile dysfunction has centred on cardiovascular-related adverse events. ${ }^{42}$ Because PDE-5 inhibitors promote vasodilation, they inherently have the potential to cause hypotension. The concern has been greatest in elderly patients with preexisting cardiovascular disease.

Mittleman and colleagues, ${ }^{43}$ in a review of 53 open-label and double-blind trials of sildenafil representing a total of
6884 patient-years of drug use and 543 patient-years of placebo use, found that the incidence of myocardial infarction was low in both the treatment and placebo groups (0.80 and 1.11 per 100 patient-years respectively) and that the rates did not differ significantly between the 2 groups. Among more than 4000 patients in clinical studies of tadalafil, the incidence of myocardial infarction in the treatment group was 0.39 per 100 patient-years, as compared with 1.1 per 100 patient-years in the placebo group. ${ }^{44}$

All PDE-5 inhibitors are contraindicated in men who

Table 3: Results of clinical trials of oral PDE-5 inhibitor therapy for erectile dysfunction (ED)

\begin{tabular}{|c|c|c|c|c|c|c|c|c|}
\hline \multirow[b]{2}{*}{ Trial } & \multirow{2}{*}{$\begin{array}{l}\text { No. of } \\
\text { patients }\end{array}$} & \multirow[b]{2}{*}{ Patients } & \multirow{2}{*}{$\begin{array}{l}\text { PDE-5 } \\
\text { inhibitor }\end{array}$} & \multirow[b]{2}{*}{ Outcome measures } & \multicolumn{2}{|c|}{ Results } & \multirow[b]{2}{*}{$p$ value } & \multirow[b]{2}{*}{ Comments } \\
\hline & & & & & Drug & Placebo & & \\
\hline $\begin{array}{l}\text { Stark } \\
\text { et } \mathrm{al}^{33}\end{array}$ & 601 & $\begin{array}{l}\text { Men with mild } \\
\text { to severe ED } \\
\text { secondary to } \\
\text { various causes }\end{array}$ & Vardenafil & $\begin{array}{l}\text { Erectile function scores } \\
\text { Successful intercourse } \\
\text { attempts }\end{array}$ & $>70 \%$ & $40 \%$ & $<0.001$ & $\begin{array}{l}\text { Drug therapy stopped in } 0.7 \% \\
\text { to } 4.8 \% \text { of patients because of } \\
\text { adverse events }\end{array}$ \\
\hline $\begin{array}{l}\text { Brock } \\
\text { et } \mathrm{al}^{34}\end{array}$ & 440 & $\begin{array}{l}\text { Men who } \\
\text { underwent } \\
\text { radical } \\
\text { prostatectomy } \\
\text { for localized } \\
\text { prostate cancer }\end{array}$ & Vardenafil & $\begin{array}{l}\text { \% with improved erections } \\
\text { (based on global-assessment } \\
\text { question) } \\
\text { - } 10 \text {-mg dose } \\
\text { - } 20 \text {-mg dose }\end{array}$ & $\begin{array}{l}59.4 \% \\
65.2 \%\end{array}$ & $\begin{array}{l}12.5 \% \\
12.5 \%\end{array}$ & $\begin{array}{l}<0.0001 \\
<0.0001\end{array}$ & $\begin{array}{l}\text { Efficacy measured after } 12 \text { wk } \\
\text { of therapy }\end{array}$ \\
\hline $\begin{array}{l}\text { Hellstrom } \\
\text { et } \mathrm{al}^{35}\end{array}$ & 805 & $\begin{array}{l}\text { Men }>18 \mathrm{yr} \\
\text { with ED lasting } \\
>6 \mathrm{mo}\end{array}$ & Vardenafil & $\begin{array}{l}\text { IIEF scores } \\
\text { - } 5 \text {-mg dose } \\
\text { - 10-mg dose } \\
\text { - 20-mg dose }\end{array}$ & $\begin{array}{l}17.79 \\
21.2 \\
21.83\end{array}$ & $\begin{array}{l}14.84 \\
14.84 \\
14.84\end{array}$ & $\begin{array}{l}<0.0385 \\
<0.0005 \\
<0.0005\end{array}$ & $\begin{array}{l}\text { Multicentred, randomized, } \\
\text { double-blind trial; } 506 \text { of original } \\
1311 \text { patients not included in } \\
\text { analysis, mostly because of } \\
\text { protocol violation }(<2 \\
\text { intercourse attempts per wk) }\end{array}$ \\
\hline $\begin{array}{l}\text { Goldstein } \\
\text { et } \mathrm{al}^{36}\end{array}$ & 452 & $\begin{array}{l}\text { Men with } \\
\text { diabetes (type } \\
1 \text { or type 2) }\end{array}$ & Vardenafil & $\begin{array}{l}\text { \% with improved erections } \\
\text { (based on global-assessment } \\
\text { question) } \\
\text { - } 10-\mathrm{mg} \text { dose } \\
\text { - } 20-\mathrm{mg} \text { dose } \\
\text { Successful intercourse } \\
\text { attempts (among patients } \\
\text { with erections sufficient for } \\
\text { penetration) } \\
\text { - } 10 \text {-mg dose } \\
\text { - } 20 \text {-mg dose }\end{array}$ & $\begin{array}{l}57 \% \\
72 \%\end{array}$ & $\begin{array}{l}13 \% \\
13 \%\end{array}$ & $\begin{array}{l}<0.0001 \\
<0.0001\end{array}$ & $\begin{array}{l}\text { Multicentred, double-blind, } \\
\text { placebo-controlled trial }\end{array}$ \\
\hline $\begin{array}{l}\text { Brock } \\
\text { et } \mathrm{al}^{37}\end{array}$ & 1112 & $\begin{array}{l}\text { Men with mild } \\
\text { to severe ED } \\
\text { secondary to } \\
\text { various causes }\end{array}$ & Tadalafil & $\begin{array}{l}\text { Normal erectile function } \\
\text { scores } \\
\% \text { of intercourse attempts } \\
\text { that were successful }\end{array}$ & $59 \%$ & $\begin{array}{l}11 \% \\
32 \%\end{array}$ & $\begin{array}{l}<0.001 \\
<0.001\end{array}$ & $\begin{array}{l}\text { Drug was well tolerated and } \\
\text { effective across various causes, } \\
\text { age groups and degrees of ED } \\
\text { severity; dyspepsia and } \\
\text { headache were most common } \\
\text { adverse events }\end{array}$ \\
\hline $\begin{array}{l}\text { Fink } \\
\text { et }^{38}{ }^{38}\end{array}$ & 6659 & $\begin{array}{l}\text { Meta-analysis } \\
\text { of } 27 \text { trials; } \\
\text { mean age of } \\
\text { patients } 55 \mathrm{yr} ; \\
\text { mean duration } \\
\text { of ED } 4.8 \mathrm{yr}\end{array}$ & Sildenafil & $\begin{array}{l}\% \text { of intercourse attempts } \\
\text { that were successful } \\
\text { At least } 1 \text { successful } \\
\text { intercourse during } \\
\text { treatment }\end{array}$ & $\begin{array}{l}57 \% \\
83 \%\end{array}$ & $21 \%$ & $-*$ & $\begin{array}{l}\text { Drug effective across various } \\
\text { subgroups and degrees of ED } \\
\text { severity }\end{array}$ \\
\hline $\begin{array}{l}\text { Carson } \\
\text { et } \mathrm{al}^{39}\end{array}$ & 2667 & $\begin{array}{l}\text { Meta-analysis } \\
\text { of } 11 \text { double- } \\
\text { blind, placebo- } \\
\text { controlled } \\
\text { trials }\end{array}$ & Sildenafil & $\begin{array}{l}\text { Multiple parameters: IIEF } \\
\text { score, questions } 3 \text { and } 4 \text { of } \\
\text { IIEF erectile function } \\
\text { domain questions, global } \\
\text { efficacy question and } \\
\text { patient log of sexual activity }\end{array}$ & $\begin{array}{l}\text { Overall } \\
\text { drug v. } \\
\text { reportec } \\
\text { significa } \\
\text { ment w } \\
\text { all subg }\end{array}$ & $\begin{array}{l}\text { icacy of } \\
\text { cebo not } \\
\text { lowever, } \\
\text { improve- } \\
\text { drug seen in } \\
\text { ups }\end{array}$ & $\begin{array}{l}<0.02 \text { to } \\
0.0001\end{array}$ & $\begin{array}{l}\text { No specific characteristic } \\
\text { predicted absolute failure with } \\
\text { sildenafil }\end{array}$ \\
\hline
\end{tabular}


use or may need to use nitrates. These drugs potentiate the vasodilatory effect of organic nitrates and nitric oxide donor drugs. ${ }^{45}$ The effect on systemic blood pressure, however, in both normotensive and hypertensive men tends to be clinically nonsignificant when sildenafil is used alone or in conjunction with other antihypertensive agents. ${ }^{46}$ Thadani and colleagues ${ }^{47}$ reported that use of vardenafil did not affect exercise tolerance among men with stable coronary artery disease. ${ }^{47}$

Other adverse events associated with oral PDE-5 inhibitor therapy appear to be few (Table 4). In clinical trials the rates of discontinuation of the drug because of adverse events was low $(<5 \%)$ for all of 3 drugs, with few or no cases of priapism. ${ }^{37,53,5,56}$ Extra caution should be taken for patients who are expected to have reduced clearance of the drug. This group includes men who have severe hepatic or renal insufficiency, men over 65 years old and men taking drugs that inhibit the cytochrome P450 3A4 enzyme (e.g., cimetidine, erythromycin and ketoconazole). ${ }^{57}$ For these patients it is prudent to start with smaller doses of medication and build up gradually. For sildenafil, it is our experience that a starting dose of $50 \mathrm{mg}$ is safe and effective for all men.

The potential effects of prolonged PDE-5 inhibition on spermatogenesis were evaluated by Hellstrom and colleagues $^{55}$ in a large cohort of men given daily doses of 10 and $20 \mathrm{mg}$ of tadalafil who were followed up for 6 months. They found no significant effect of the drug on reproductive hormones or sperm parameters.

\section{Alternative treatments}

If erectile dysfunction is determined to be secondary to a hypogonadal state, often after an unsuccessful trial of PDE5 inhibitors, exogenous testosterone therapy is indicated.
Currently, it is believed that a metabolite of testosterone, dihydrotestosterone, enhances the production of nitric oxide, thereby producing the clinical effect. ${ }^{58}$

Several other, more invasive options exist for patients who do not respond to PDE-5 inhibitor therapy or in whom it is contraindicated. Alprostadil (prostaglandin $\mathrm{E}_{1}$ ) causes smooth-muscle relaxation and subsequent vasodilation by acting on adenylate cyclase to increase the intracellular cyclic adenosine monophosphate (cAMP) concentration. Prostaglandin $\mathrm{E}_{1}$ may be administered intraurethrally, where it is absorbed and transported throughout the erectile bodies. The reported efficacy of intraurethral alprostadil therapy is variable. Padma-Nathan and colleagues ${ }^{59}$ reported a response rate of $65.9 \%$. Fulgham and associates ${ }^{60}$ noted improvement in $30 \%$ of patients; however, this study has been criticized for inadequate dose titration. ${ }^{61}$ The most common side effect of intraurethral alprostadil therapy is local penile pain caused by drug-mediated sensitization of nerve fibres. ${ }^{60}$

Vasoactive drugs may also be injected intracavernosally. Such therapy represents an important second-line therapy for erectile dysfunction. It is the most effective pharmacologic treatment but has a high dropout rate because of the associated pain and apprehension involved. Phentolamine is an $\alpha$-blocker that was used in initial studies; its efficacy is poor, but it may be used in combination with other agents. Papaverine is a nonspecific PDE inhibitor and was the first effective intracavernosal therapy for erectile dysfunction. Currently, intracavernosal alprostadil therapy is preferred; it is more effective than other agents and produces fewer side effects. In a comparison study comparing alprostadil, a papaverine-phentolamine combination and papaverine alone, rates of success (ability to achieve and maintain an erection) of $72 \%, 61 \%$ and $31 \%$ were reported respectively. ${ }^{54}$ No patients in the alprostadil group experienced pri-

Table 4: Adverse events reported in studies comparing PDE-5 inhibitors with placebo

\begin{tabular}{|c|c|c|c|c|c|c|}
\hline \multirow[b]{2}{*}{ Adverse event } & \multicolumn{6}{|c|}{ Group; $\%$ of patients } \\
\hline & $\begin{array}{c}\text { Sildenafil } \\
(25-100 \mathrm{mg})\end{array}$ & Placebo & $\begin{array}{l}\text { Vardenafil } \\
\text { (5-20 mg) }\end{array}$ & Placebo & $\begin{array}{c}\text { Tadalafil } \\
(2.5-20 \mathrm{mg})\end{array}$ & Placebo \\
\hline Headache & $14-30$ & $4-6$ & $6.8-15.3$ & 3.9 & $7-21$ & 6 \\
\hline Flushing & $13-27$ & $1-2$ & $10.2-11.3$ & 0.7 & $1-5$ & 2 \\
\hline Dyspepsia & $2-16$ & $1-2$ & $0.7-6.7$ & 0 & $1-17$ & 2 \\
\hline $\begin{array}{l}\text { Rhinitis or nasal } \\
\text { congestion }\end{array}$ & $1-11$ & 2 & $2.8-7.3$ & 3.3 & $4-6$ & 4 \\
\hline Nausea & $1-6$ & 1 & NR & NR & NR & NR \\
\hline Dizziness & NR & NR & NR & NR & NR & NR \\
\hline Visual disturbance & $0-11$ & $\leq 2$ & $<1-2$ & 0 & 0.1 & 0 \\
\hline Back pain & $0-6$ & 2 & NR & NR & $3-9$ & 5 \\
\hline Myalgia & NR & NR & NR & NR & $1-7$ & 2 \\
\hline Yawning & NR & NR & NR & NR & NR & NR \\
\hline Somnolence & NR & NR & NR & NR & NR & NR \\
\hline Pharyngitis & $N R$ & NR & $N R$ & NR & NR & NR \\
\hline
\end{tabular}

Note: $\mathrm{NR}=$ not reported

Source: Dula et al ${ }_{1}^{48}$ Bukofzer et al ${ }^{49}$ Montorsi et al, ${ }^{50}$ Carson et al ${ }_{,}^{39,51}$ Goldstein et al,$^{52}$ Porst et al ${ }_{,}^{41,53,54}$ Hellstrom et al ${ }^{35,55}$ and Brock et al. ${ }^{37}$ 
apism, as compared with $2 \%$ and $4 \%$ of patients in the combination therapy and papaverine-only groups respectively. On the other hand, patients who used alprostadil were the only ones to report penile pain. For patients who do not respond to or do not tolerate alprostadil monotherapy, a triple mixture of papaverine, phentolamine and alprostadil may be prescribed. Such combination therapy has been shown to be more effective and, because of a lower dose of alprostadil, results in less pain. ${ }^{62}$ Complications of intracavernosal injections include pain, priapism and fibrotic changes at injection sites.

Nonpharmacologic options may be offered as secondline treatment in lieu of intraurethral or intracavernosal injection for patients who do not respond to or cannot tolerate oral therapy. Vacuum erection devices increase corporal blood flow, and a constrictor ring is then used to retain this blood within the penis. Satisfaction is variable $(27 \%-74 \%)$, and this technique can cause discomfort and bruising of the penis. ${ }^{63}$ Surgical options exist for patients with erectile dysfunction. Penile arterial bypass surgery is appropriate in only a select group of patients (men under 35 years of age who have no generalized vascular disease and in whom an isolated injury has obstructed blood flow). Penile implants are available for patients who have not responded to more conservative treatment. This procedure is invasive, irreversible and subject to complications such as infection, erosion and mechanical failure. There is, however, a high rate of patient and partner satisfaction. ${ }^{63}$

\section{Conclusion}

Dramatic advances in the management of erectile dysfunction have occurred over the past decade. Most patients with the condition are now managed by primary care physicians and specialists other than urologists. A thorough clinical examination can help to differentiate from the numerous causes of erectile dysfunction. Oral therapy with a PDE-5 inhibitor (sildenafil, vardenafil or tadalafil) should be considered for first-line treatment of erectile dysfunction. Although PDE-5 inhibitors should not be given to patients taking nitrates, because of the risk of hypotension, in general they are well tolerated by the majority of patients. Those who do not respond to this first-line therapy should be referred to a urologist for further evaluation and consideration of alternative treatments.

\section{This article has been peer reviewed.}

From the Division of Urology, Faculty of Medicine and Dentistry, University of Western Ontario, London, Ont.

Competing interests: None declared for Luke Fazio. Gerald Brock owns stocks in, and receives consultancy fees, speaker fees and travel assistance from, Bayer Inc., GlaxoSmithKline Inc., Eli Lilly Canada Inc. and Pfizer Canada Inc.

Contributors: Both authors contributed substantially to the writing of the article and approved the final version submitted for publication.

\section{References}

1. NIH Consensus Conference on Impotence. NIH Consensus Development Panel on Impotence. FAMA 1993;270:83-90.

2. Nicolosi A, Moreira ED Jr, Shirai M. Epidemiology of erectile dysfunction in four countries: cross-national study of the prevalence and correlates of erectile dysfunction. Urology 2003;61(1):201-6.

3. Seftel AD. Erectile dysfunction in the elderly: epidemiology, etiology and approaches to treatment. 7 Urol 2003;169(6):1999-2007.

4. Mulcachy JJ. Erectile dysfunction - Is the incidence increasing? [editorial] 7 Urol 2000;163:471.

5. Kleinman KP, Feldman HA, Johannes CB, Derby CA, McKinlay JB. A new surrogate variable for erectile dysfunction status in the Massachusetts Male Aging Study. 7 Clin Epidemiol 2000;53(1):71-8.

6. Johannes CB, Araujo AB, Feldman HA, Derby CA, Kleinman KP, McKinlay JB. Incidence of erectile dysfunction in men 40 to 69 years old: longitudinal results from the Massachusetts Male Aging Study. 7 Urol 2000;163(2):460-3.

7. Brock G. Erectile dysfunction update education forum summary. Can $\mathcal{F}$ Urol 2000;8:1416-8

8. Lue TF. Erectile dysfunction. N Engl F Med 2000;342:1802-13.

9. Andersson KE, Wagner G. Physiology of penile erections [review]. Physiol Rev 1995;75:191-236.

10. Burnett AL. Nitric oxide in the penis: physiology and pathology. 7 Urol 1997;157:320-4.

11. Lincoln TM. Cyclic GMP and mechanisms of vasodilation. Pharmacol Ther 1989;41:479-502.

12. Sáenz de Tejada I. Molecular mechanisms for the regulation of penile smooth muscle contractility. Int 7 Impot Res 2000;12(Suppl 4):S34-8.

13. Stief CG, Uckert S, Becker AJ, Truss MC, Jonas U. The effect of the specific phosphodiesterase (PDE) inhibitors on human and rabbit cavernous tissue in vitro and in vivo. 7 Urol 1998;159(4):1390-3.

14. Bancroft $\mathrm{J}, \mathrm{Wu}$ FCW. Changes in erectile responsiveness during androgen replacement therapy. Arch Sex Behav 1983;12:59-66.

15. Kwan M, Greenleaf WJ, Mann J, Crapo L, Davidson JM. The nature of androgen action on male sexuality: a combined laboratory/self-reported study on hypogonadal men. 7 Clin Endocrinol Metab 1983;57(3):557-62.

16. Saenz de Tejada I, Blanco R, Goldstein I, Azadzoi K, de las Morenas A, Krane RJ, et al. Cholinergic neurotransmission in human corpus cavernosum. I. Response of isolated tissue. Am 7 Physiol 1988;254(3 Pt 2):H459-67.

17. Rampin O, Giuliano F. Brain control of penile erection. 7 Urol 2001;19(1):1-8.

18. Giuliano F, Allard J. Apomorphine SL (Uprima): preclinical and clinical experiences learned from the first central nervous system-acting ED drug [review]. Int 7 Impot Res 2002;14(Suppl 1):S53-6.

19. Mulligan T, Schmitt B. Testosterone for erectile failure. F Intern Med 1993;8: $517-21$.

20. Kaiser FE, Viosca SP, Morley JE, Mooradian AD, Davis SS, Korenman SG. Impotence and aging: clinical and hormonal factors. 7 Am Geriatr Soc 1988; 36:511-9.

21. Bors E, Comar AE. Neurological urology: physiology of micturition, its neurological disorders and sequelae. Baltimore: University Park Press; 1971

22. Siegel T, Moul JW, Spevak M, Alvord G, Costabile RA. The development of erectile dysfunction in men treated for prostate cancer. 7 Urol 2001;165:430-5.

23. Brock GB, Lue TF. Drug-induced sexual dysfunction: an update. Drug Safety 1993;8:414-26.

24. McVary KT, Carrier S, Wessells H; Subcommittee on Smoking and Erectile Dysfunction Socioeconomic Committee, Sexual Medicine Society of North America. Smoking and erectile dysfunction: evidence based analysis. 7 Urol 2001;166(5):1624-32.

25. Martin-Morales A, Sanchez-Cruz JJ, Saenz de Tejada I, Rodriguez-Vela L, Jiminez-Cruz JF, Burgos-Rodriguez R. Prevalence and independent risk factors for erectile dysfunction in Spain: results of the epidemiologia de la disfuncion erectila masculina study. 7 Urol 2001;166:569-74.

26. Romeo JH, Seftel AD, Madhun ZT, Aron DC. Sexual function in men with diabetes type 2: association with glycemic control. F Urol 2000;163:788-91.

27. Nickel JC, Morales A, Condra M, Fenemore J, Surridge DH. Endocrine dysfunction in impotence: incidence, significance, and cost-effective screening. 7 Urol 1984;132(1):40-3.

28. Canadian Urological Association Guidelines Committee. Erectile dysfunction practice guidelines. Can 7 Urol 2002;9(4):1583-7.

29. Rosen RC, Cappelleri JC, Smith MD, Lipsky J, Pena BM. Development and evaluation of an abridged, 5-item version of the International Index of Erectile Function (IIEF-5) as a diagnostic tool for erectile dysfunction. Int 7 Impot Res 1999;11:319-26.

30. Chun J, Carson CC III. Physician-patient dialogue and clinical evaluation of erectile dysfunction. Urol Clin North Am 2001;28(2):249-58, viii.

31. Ralph D, McNicholas T. UK management guidelines for erectile dysfunction. BMF 2000;321:499-503.

32. Beavo JA. Cyclic nucleotide phosphodiesterases: functional implications of multiple isoforms. Physiol Rev 1995;75:725-48.

33. Stark S, Sachse R, Liedl T, Hensen J, Rohde G, Wensing G, et al. Vardenafil 
increases penile rigidity and tumescence in men with erectile dysfunction after a single oral dose. Eur Urol 2001;40:181-8.

34. Brock G, Nehra A, Lipshultz LI, Karlin GS, Gleave M, Seger M, et al. Safety and efficacy of vardenafil for the treatment of men with erectile dysfunction subsequent to radical retropubic prostatectomy. F Urol 2003;170(4 Pt 1): 1278-83.

35. Hellstrom WJ, Gittelman M, Karlin G, Segerson T, Thibonnier M, Taylor $\mathrm{T}$, et al; Vardenafil Study Group. Sustained efficacy and tolerability of vardenafil, a highly potent selective phosphodiesterase type 5 inhibitor, in men with erectile dysfunction: results of a randomized, double-blind, 26-week placebo-controlled pivotal trial. Urology 2003;61(4 Suppl 1):8-14.

36. Goldstein I, Young JM, Fischer J, Bangerter K, Segerson T, Taylor T; Vardenafil Diabetes Study Group. Vardenafil, a new phosphodiesterase type 5 inhibitor, in the treatment of erectile dysfunction in men with diabetes: a multicenter doubleblind placebo-controlled fixed-dose study. Diabetes Care 2003;26(3):777-83.

37. Brock GB, McMahon CG, Chen KK, Costigan T, Shen W, Watkins V, et al. Efficacy and safety of tadalafil in the treatment of erectile dysfunction: results of integrated analyses. 7 Urol 2002;168:1332-8.

38. Fink HA, Mac Donald R, Rutks IR, Nelson DB, Wilt TJ. Sildenafil for male erectile dysfunction: a systematic review and meta-analysis [review]. Arch Intern Med 2002;162(12):1349-60.

39. Carson CC, Burnett AL, Levine LA, Nehra A. The efficacy of sildenafil citrate (Viagra) in clinical populations: an update [review]. Urology 2002;60(2 Suppl 2):12-27.

40. Brock G. Tadalafil for the treatment of erectile dysfunction. Urol Rev 2002; 168:1332-6.

41. Porst H, Padma-Nathan H, Giuliano F, Anglin G, Varanese L, Rosen RC. Efficacy of tadalafil for the treatment of erectile dysfunction at 24 and 36 hours after dosing a randomized controlled trial. Urology 2003;62:121-5.

42. Arora RR, Timoney M, Melilli L. Acute myocardial infarction after the use of sildenafil [letter]. N Engl 7 Med 1999;341:700.

43. Mittleman MA, Glasser DB, Razem J, et al: Incidence of myocardial infarction and death in 53 clinical trials of Viagra (sildenafil citrate). 7 Am Coll Cardiol 2000;35:302A.

44. Kloner RA, Watkins VS, Costigan TM, Bedding A, Mitchell MI, Emmick J Cardiovascular profile of tadalafil, a new PDE5 inhibitor [abstract 707]. $\mathcal{F}$ Urol 2002;167(Suppl 4):176.

45. Webb DJ, Freestone S, Allen MJ, Muirhead GJ. Sildenafil citrate and bloodpressure lowering drugs: results of drug interaction studies with organic nitrate and a calcium antagonist. Am 7 Cardiol 1999;83(5A):21C-8C.

46. Vardi Y, Klein L, Nassar S, Sprecher E, Gruenwald I. Effects of sildenafil citrate (Viagra) on blood pressure in normotensive and hypertensive men. Urology 2002;59:747-52

47. Thadani U, Smith W, Nash S, Bittar N, Glasser S, Narayan P, et al. The effect of vardenafil, a potent and highly selective phosphodiesterase- 5 inhibitor for the treatment of erectile dysfunction, on the cardiovascular response to exercise in patients with coronary artery disease. 7 Am Coll Cardiol 2002;4;40(11):2006-12.

48. Dula E, Bukofzer S, Perdok R, George M; Apomorphine SL Study Group. Double-blind, crossover comparison of $3 \mathrm{mg}$ apomorphine SL with placebo and with $4 \mathrm{mg}$ apomorphine SL in male erectile dysfunction. Eur Urol 2001;39:558-63.

49. Bukofzer S, Livesey N. Safety and tolerability of apomorphine SL (Uprima). Int 7 Impot Res 2001;13(Suppl 3):S40-4.

50. Montorsi F, McDermott TE, Morgan R, Olsson A, Schultz A, Kirkeby HJ, et al. Efficacy and safety of fixed-dose oral sildenafil in the treatment of erectile dysfunction of various etiologies. Urology 1999;53:1011-8.

51. Carson CC, Burnett AL, Levine LA, Nehra A. The efficacy of sildenafil citrate (Viagra) in clinical populations. An update. Urology 2002;60(Suppl 2B):12-27.

52. Goldstein I, Lue TF, Padma-Nathan H, Rosen RC, Steers WD, Wicker PA. Oral sildenafil in the treatment of erectile dysfunction. Sildenafil Study Group [published erratum in NEngl f Med 1998;339:59]. N Engl 7 Med 1998;338:1397-404.

53. Porst H, Rosen R, Padma-Nathan H, Goldstein I, Giuliano F, Ulbrich E, et al. The efficacy and tolerability of vardenafil, a new, oral, selective phosphodiesterase type 5 inhibitor, in patients with erectile dysfunction: the first athome clinical trial. Int 7 Impot Res 2001;13(4):192-9.

54. Porst H. [Prostaglandin E1 in erectile dysfunction] [article in German]. Urologe A 1989;28:94-8.

55. Hellstrom WJ, Overstreet JW, Yu A, Saikali K, Shen W, Beasley M Jr, Watkins VS. Tadalafil has no detrimental effect on human spermatogenesis or reproductive hormones. 7 Urol 2003;170(3):887-91.

56. Saenz de Tejada I, Anglin G, Knight JR, Emmick JT. Effects of tadalafil on erectile function in men with diabetes. Diabetes Care 2002;25(12):2159-64.
57. Padma-Nathan H, Giuliano F. Oral drug therapy for erectile dysfunction. Urol Clin North Am 2001;28(2):321-34.

58. Kalinchenko SY, Kozlov GI, Gontcharov NP, Katsiya GV. Oral testosterone undecanoate reverses erectile dysfunction associated with diabetes mellitus in patients failing on sildenafil citrate therapy alone. Aging Male 2003;6(2):94-9.

59. Padma-Nathan $H$, Hellstrom WJ, Kaiser FE, Labasky RF, Lue TF, Nolten WE, et al. treatment of men with erectile dysfunction with transurethral alprostadil. Medicated Urethral System for Erection (MUSE) Study Group. $N$ Engl 7 Med 1997;336:1-7.

60. Leungwattanakij S, Flynn V, Hellstrom WJG. Intracavernosal injection and intraurethral therapy for erectile dysfunction. Urol Clin North Am 2001;28(2):343-54.

61. Fulgham PF, Cochran JS, Denman JL, Feagins BA, Gross MB, Kadesky K'T Disappointing initial results with the transurethral alprostadil for erectile dysfunction in a urology practice setting. 7 Urol 1998;160(6 Pt 1):2041-6.

62. Bennett AH, Carpenter AJ, Baranda JH. An improved vasoactive drug combination for a pharmacologic erection program. 7 Urol 1991;146:1564-5.

63. Hatzichristou DG, Pescatori ES. Current treatments and emerging therapeutic approaches in male erectile dysfunction. Br F Urol 2001;88(Suppl 3):11-7.7

Correspondence to: Dr. Gerald Brock, Division of Urology, Faculty of Medicine and Dentistry, University of Western Ontario 268 Grosvenor St., London ON N6A 4V2; fax 519 646-6037; gebrock@sympatico.ca

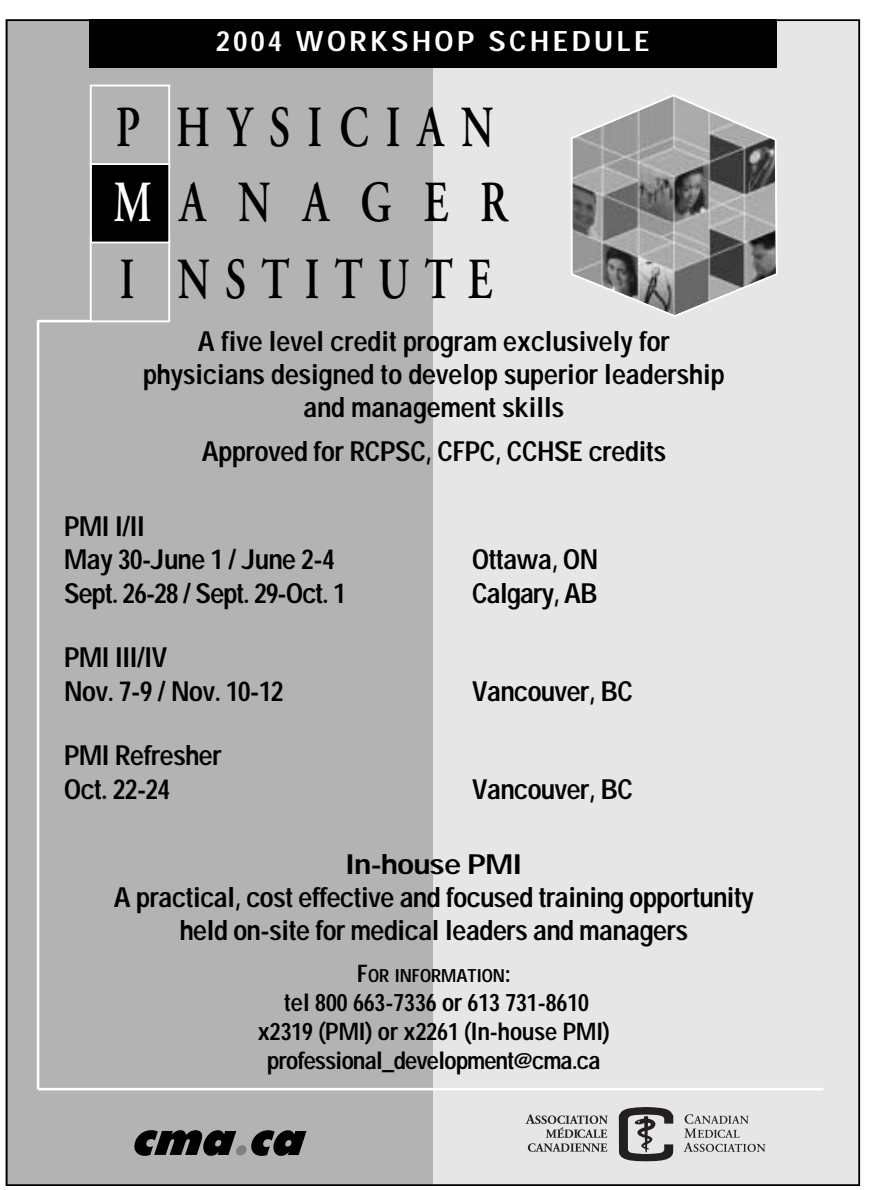

